\title{
Analysis of Trust through Academic Information System and Image of Private University
}

\author{
Realize \\ University of 17 Agustus 1945 Surabaya
}

\begin{abstract}
Private universities must have a uniqueness that distinguishes them from others and it becomes a distinctive feature that gives its own appraisal in the hearts of people. This uniqueness can grow a good image and can bring public confidence. Efforts to build trust for a university absolutely must be done in order to maintain existence. This study aims to analyze trust through the use of academic information systems and private university image. This study uses students from private universities in Kepulauan Riau province as respondents who fill questionnaires distributed by using proportional sampling technique. Structural Equation Modeling (SEM) is used as a tool in analyzing data. Result of the research based on hypothesis analysis and test show that academic information system has significant influence on direct image and trust of private universities in province of Kepulauan Riau. This shows that with the use of Academic Information Systems students in lecturing activities are able to grow a good image for private universities that finally ic can increase public confidence.
\end{abstract}

Keywords: academic information system, image, trust, private university

\section{INTRODUCTION}

The new paradigm has delivered universities to the competition orientation not only at the national level, whether competition occurs among private universities or private universities with state universities, but the competition lately has shifted to the global. The latest facts show that foreign universities entering Indonesia are no longer limited to comparative studies or collaboration, but they also do promotion to recruit prospective students. The effort to build trust for a college must be done in order to maintain existence by improving the quality of research and publication, utilizing the website optimally, cooperating with foreign universities to increase the number of lecturers and international students, optimizing International Program (IP) and Internationalization of local journals.

Lupiyoadi states that the marketing of services is any action offered by one of the parties which is principally intangible and does not cause any transfer of ownership [12]. Service marketing has become a major part of current economic activity. One of them is in the education sector conducted by universities. Colleges, especially private colleges must have the ability to capture every symptom of environmental change that becomes the determining factor of success, able to maintain the continuity of its vision with the attention to service to society, curriculum / teaching, Student life), physical operations / infrastructure, research and scholarship, policy planning and administration [3]. Private universities should have their own characteristics that are able to distinguish them from other universities from state universities or private universities, for example Entrepreneur IT-based Campus, Cooperative, Tourism Economy [20]. These become capital to get a good assessment of service users who will build the image of the college. A good image is not only a fame but also a reputation. A good image of college will make dreams of students and prospective students and determinants of growing relationships of stakeholders especially to regain public confidence [7]. 
Trust is a very important role to build a long-term cooperative relationship. Because the relationship formed due to the existence of high trust and excellent communication so that it will arise the desire of the stake holders who concern to implement their commitments. Trust must be grown by each stake holder.

\section{Academic Information System}

\section{LITERATURE REVIEW}

Increasing organizational dependence on information systems encourages management's attention to improving the quality of information systems. Improving the quality of information technology (IT) is one of the main concerns facing IT executives. Because IT quality is a multidimensional measure, it is important to determine which aspects of IT quality are important for the organization to help Chief Information Officers (CIOs) design effective IT quality improvement strategies [6]. A Management Information System is defined as a computer-based system that makes information available for users who have similar needs [14].

Management information systems are not only developed based on the needs of each level of management but have also been developed based on the functional areas of management. Including in educational institutions or colleges. Raymond and Bergeron said that the quality of information output by the Performance Management Information System (PMIS) is closely related to the technical aspects and system services, namely system quality [15]. Like the company, the pattern of management applied to the college is so varied that the management information system applied also varies according to the needs of each. However, in principle, the prevailing management information system still refers to the implementation of tri dharma activities of higher education, namely activities of teaching, research and community service as well as points of assessment contained in accreditation forms of higher education. The management information system commonly used today in universities such as academic information systems, student and graduate information systems, financial information systems, library information systems, facilities and infrastructure information systems, as well as personnel information systems.

\section{Image}

Customer in determining the choice of a product not only based on necessity, but there are other things that are expected. Image has been introduced in the 1950s in various contexts such as image organization (organization image), corporate image, national image, brand image And many others. Image is a collection of tangible and intangible nature such as ideas, beliefs, values, interests and features that make them different from others [7]. The image is an impression received and felt by someone based on knowledge and understanding of facts or reality [1]. The image is formed based on knowledge and information received by someone.

The reputation of the company plays very important role to foster stakeholder relations especially to regain public confidence. The company's reputation comes from corporate interactions with its stakeholders. It emphasizes the importance of pride in membershiprelated employee awareness in the management of corporate reputation [8].

\section{Trust}

Morgan and Hunt argue that belief occurs when a person is convinced by the reliability and integrity of a trusted person [2]. Trust is directed to others where people can trust the characteristics of others. The results of Kim et al showed that consumer confidence is one factor that has a strong impact on consumer purchasing decisions, especially having a strong effect on Internet consumer confidence on the Web Site [10]. According to Mayer et al. there 
are three factors which make up one's belief in [16], namely:

1. Ability

The ability of the seller / organization to influence or authorize a specific region. Able to provide, serve, to secure transactions from interference from others.

2. Kindness (Benevolence)

The seller can provide mutually benefits between himself and the consumer. Profit obtained by the seller can be maximized, but customer satisfaction is also high. Sellers are not pursuing the maximum profit only, but also have a great attention in realizing consumer desires.

3. Integrity (Integrity)

Integrity relates to how the seller's behavior or habits in running the business. The information given to the consumer is true to the facts or not. The quality of the products / services sold is reliable or not.

\section{RESEARCH METHOD}

The population in this study are students who come from private universities in Kepulauan Riau province. Samples are distributed using proportional sampling technique to active students and at least at semester 5 [13][17]. Data collection technique used the distribution of questionnaires filled out by 304 respondents in accordance with the number of samples [11] [18].

All variables are assessed on a five-point Likert scale that strongly agrees, agrees, neutrals, disagrees and strongly disagrees [4][13]. Confirmatory factor analysis is used to test the goodness of fit of the data set. To assess the effect of academic information system and image on credibility, structural equation modeling using the amos software version 22 . The structural model of the variables measured in this study are as follows:

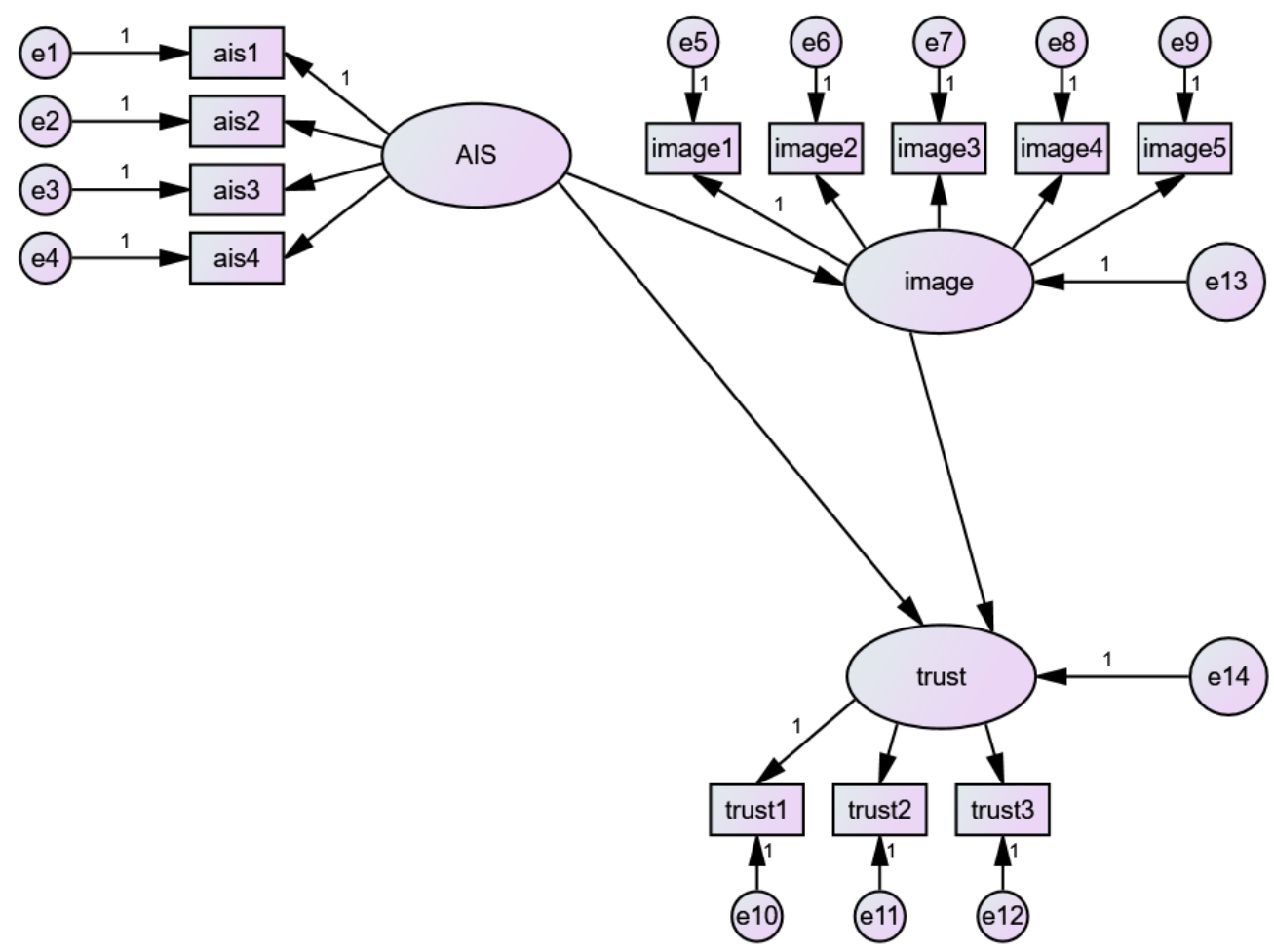

Figure 1

Structural Model of Research 


\section{RESULTS AND DISCUSSION}

Based on the results of the test by using amos version 22, Hoelter Index on text output is 316. The sample used in the research is 304 samples, this means that the sample used is enough to draw the conclusion because the sample number is smaller than the Hoelter Index value [5].

Description of the number of respondents by sex of the majority of men although actually almost equal to the number of female sex. Description of the number of respondents by age is dominated by respondents at age range 21 - 25 years old and at least is the respondent aged more than 30 years. This shows that the majority of private college students in Kepulauan Riau province are not fresh graduates, and based on field observations and interviews it is found that in general they are workers in industrial companies. The number of respondents based on respondent study program is dominated by respondents from Information System study program. Characteristics of respondents based on the study period seen from the level of semester that is being pursued by students, obtained data respondents who are in semester 5 (five) is the most respondents in this study. These results indicate that the majority of private university students in Kepulauan Riau are workers in companies. They are still young and have a tendency to choose the field of computer science.

\section{Validity}

In this research, validity test is done on each variable indicator to its construct using loading factor or lamda coefficient $(\lambda)$. A model can be said fit if loading factor value is greater than $0.50[5]$.

Table 1 illustrates that all variable indicators have a critical ratio (CR) greater than twice their standard error (SE) value and have a probability value less than 0.05 . The results of this test indicate that these indicators have satsified the requirements of construct validity.

Tabel 1.

Loading Factor Value

\begin{tabular}{|ccc|c|c|c|c|}
\hline & & & $\mathrm{P}$ & S.E. & Critical Ratio & Loading Factor \\
\hline ais1 & $<---$ & AIS & 0,000 & 0.069 & 13.893 & 0.813 \\
ais2 & $<---$ & AIS & 0,000 & 0.07 & 14.8 & 0.872 \\
ais3 & $<---$ & AIS & Ref & Ref & Ref & 0.837 \\
ais4 & $<---$ & AIS & 0,000 & 0.058 & 15.047 & 0.747 \\
\hline image1 & $<---$ & image & Ref & Ref & Ref & 0.782 \\
image2 & $<---$ & image & 0,000 & 0.072 & 13.462 & 0.755 \\
image3 & $<---$ & image & 0,000 & 0.069 & 14.821 & 0.82 \\
image4 & $<---$ & image & 0,000 & 0.075 & 13.795 & 0.782 \\
image5 & $<---$ & image & 0,000 & 0.073 & 13.196 & 0.74 \\
\hline trust1 & $<---$ & trust & 0,000 & 0.034 & 26.256 & 0.88 \\
trust2 & $<---$ & trust & 0,000 & 0.03 & 33.416 & 0.952 \\
trust3 & $<---$ & trust & Ref & Ref & Ref & 0.95 \\
\hline
\end{tabular}

\section{Reliability}

Reliability testing done by using two approaches, they are construct reliability (CR) with values equal to 0.70 and Variance Extracted (AVE) with values greater than or equal to 0.50 [5]. Table 2 shows that the value of construct reliability (CR) is greater than 0.70 and the value of variance extracted (AVE) is greater than 0.50 . The results of this test indicate that these indicators have satisfied the reliability test requirements. 
Tabel 2.

Construct Reliability value

\begin{tabular}{|ccc|c|c|c|c|}
\hline & & $\begin{array}{c}\text { Loading } \\
\text { Factor }\end{array}$ & $\begin{array}{c}\text { Measurement } \\
\text { Error }\end{array}$ & $\begin{array}{c}\text { Construct } \\
\text { Reliability }\end{array}$ & $\begin{array}{c}\text { Variance } \\
\text { Extracted }\end{array}$ \\
\hline ais1 & $<---$ & AIS & 0.813 & 0.339 & 0.890 & 0.670 \\
ais2 & $<---$ & AIS & 0.872 & 0.240 & & \\
ais3 & $<---$ & AIS & 0.837 & 0.299 & & \\
ais4 & $<---$ & AIS & 0.747 & 0.442 & & 0.603 \\
\hline image1 & $<---$ & image & 0.782 & 0.388 & 0.883 & \\
image2 & $<---$ & image & 0.755 & 0.430 & & \\
image3 & $<---$ & image & 0.82 & 0.328 & & \\
image4 & $<---$ & image & 0.782 & 0.388 & & \\
image5 & $<---$ & image & 0.74 & 0.452 & & \\
\hline trust1 & $<---$ & trust & 0.88 & 0.226 & 0.949 & \\
trust2 & $<---$ & trust & 0.952 & 0.094 & & \\
trust3 & $<---$ & trust & 0.95 & 0.098 & & \\
\hline
\end{tabular}

\section{Normality}

Normality testing is done by looking at the value of kurtosis from the data used. Variables that have a skewness or kurtosis coefficient with a critical ratio of not more than \pm 2.58 indicate a normal distribution [5].

Table 3.

Normality value

\begin{tabular}{|lrrrrrr|}
\hline \multicolumn{1}{|c}{ Variable } & \multicolumn{1}{c}{ Min } & \multicolumn{1}{c}{ Max } & \multicolumn{1}{c}{ Skew } & \multicolumn{1}{c}{ c.r. } & \multicolumn{1}{c|}{ kurtosis } & \multicolumn{1}{c|}{ c.r. } \\
\hline ais4 & 2 & 5 & 0.048 & 0.343 & -0.603 & -2.144 \\
trust1 & 2 & 5 & -0.071 & -0.504 & -0.133 & -0.475 \\
trust2 & 1.67 & 5 & -0.141 & -1.004 & -0.214 & -0.762 \\
trust3 & 1.67 & 5 & -0.126 & -0.899 & -0.08 & -0.285 \\
image5 & 2 & 5 & 0.173 & 1.23 & -0.091 & -0.326 \\
image4 & 2 & 5 & -0.147 & -1.045 & -0.475 & -1.692 \\
image3 & 2 & 5 & 0.127 & 0.901 & 0.299 & 1.065 \\
image2 & 2 & 5 & -0.104 & -0.742 & -0.39 & -1.388 \\
image1 & 2 & 5 & 0.055 & 0.391 & -0.243 & -0.864 \\
ais1 & 1 & 5 & 0.024 & 0.169 & -0.173 & -0.614 \\
ais2 & 2 & 5 & -0.29 & -2.065 & -0.391 & -1.391 \\
ais3 & 2 & 5 & -0.056 & -0.401 & -0.421 & -1.5 \\
Multivariate & & & & & 8.289 & 3.942 \\
\hline
\end{tabular}

Table 3 illustrates that all indicators have a critical ratio value of Kurtosis value and Skewness value of not more than \pm 2.58 , except multivariate normality. However, this value is less than 8 , then allowed for analysis can be continued [5]. This means that the data used in the study is normally distributed and very feasible for subsequent estimates use. 


\section{Structural Model}

Goodness of Fit calculation results of the initial model of research indicate there are criteria that have not satisfy the established standards. Based on the theoretical considerations, modification of the index to the model by not changing the result of causality (parameter) significantly. The results of the calculation of Goodness of Fit index values produced by the structural model after the index modification. They are as follow:

Table 4.

Nilai Goodness of Fit value on Modified Model

\begin{tabular}{|l|c|c|c|}
\hline \multicolumn{1}{|c|}{$\begin{array}{c}\text { Goodness of Fit } \\
\text { Measure }\end{array}$} & Indeks & Cut Off & Explanation \\
\hline $\begin{array}{l}\text { Chi-square of estimate } \\
\text { model }\end{array}$ & 64.829 & & Fit model \\
\hline Probability Level & 0.077 & $>0.05$ & Fit model \\
\hline $\begin{array}{l}\text { Goodness of Fit index } \\
\text { (GFI) }\end{array}$ & 0.967 & $\geq 0.9$ & Fit model \\
\hline $\begin{array}{l}\text { Adjusted Goodness of } \\
\text { Fit Index (AGFI) }\end{array}$ & 0.949 & $\geq 0.9$ & Fit model \\
\hline $\begin{array}{l}\text { Tucker-Lewis Index } \\
\text { (TLI) }\end{array}$ & 0.992 & $\geq 0.9$ & Fit model \\
\hline $\begin{array}{l}\text { Comparative Fit Index } \\
\text { (CFI) }\end{array}$ & 0.994 & $\leq 0.9$ & \\
\hline RMSEA & 0.031 & & \\
\hline
\end{tabular}

Table 4 illustrates that the results of the Goodness of Fit model modification give the conformity index value that has satisfied the recommended standard that is above the cutoff value specified. It can be concluded that the structural model is fit or has good and acceptable conformity.

Table 5.

Coefisien of Variabcl between Was

\begin{tabular}{|ccc|cccc|}
\hline & & & $\begin{array}{c}\text { Standardized } \\
\text { Estimate }\end{array}$ & C.R. & P & Explanation \\
\hline image & $<---$ & AIS & 0.265 & 4.093 & 0.000 & Significant \\
trust & $<---$ & AIS & 0.586 & 10.050 & 0.000 & Significant \\
trust & $<---$ & image & 0.115 & 2.145 & 0.032 & Significant \\
\hline
\end{tabular}

The parameter relationship with others is shown in Table 5. The critical ratio (CR) value that is the same with the $t$ test in the regression analysis shows that all the regression coefficients are not significantly equal to zero. Thus hypothesis 0 which states that the regression coefficient equal to zero can be rejected and the causality relationship in the research model is acceptable.

\section{Academic information system has significantly influence on the image}

Table 5 illustrates that the regression coefficient between the academic information system variables on the image is 0.265 with the critical ratio value of 4,093 and the probability value 0.000 . It states that academic information system variables significantly affect the image. The results of this study are consistent with the results of a study conducted by Venkatesh et al. (2012) that improves the performance of technology also increases the reputation of a product so that customers continue to support all the models produced [19].

\section{The image has a significant effect on trust}

Table 5 illustrates that the regression coefficient between the image variables to the trust is 0.115 with the critical ratio value of 2.145 and the probability value 0.032 . It states that the 
image variable has significant effect on the trust. The results of this study in accordance with research conducted Helm (2011) is the company's reputation is very important to grow the relationship of stakeholders, especially to regain public confidence [8].

\section{Academic information system has significant effect on trust}

Table 5 illustrates that the regression coefficient between the academic information system variable to the trust is 0.586 with the critical ratio value of 10,050 and the probability value 0.000 . It states that the image variable has significant effect on the trust. The results of this study in accordance with research conducted Hotlan et al. (2014) that improving the quality of information technology services in the fulfillment of consumer needs will make the higher the trust received from consumers [9]. The test results also indicate there is significant influence of academic information system variable indirectly to the trust through image with the value of 0.031 .

\section{CONCLUSION}

This research resulted some findings that academic information system have significant effect to image and comply with the result of research of Venkatesh et al. (2012), the image has a significant effect on trust and comply with the results of Helm (2011) as well as academic information system have a significant effect on trust and support Hotlan research results (2014).

\section{SUGGESTION}

This study has some limitations because it does not cover all the indicators of academic information system variables. Image and belief as suggested by previous researchers. Although the sample number has satisfied the requirements for SEM. Larger samples are still needed to make generalizations. Beside that this research is located in Kepulauan Riau province in Indonesia which is still in developing stage in the field of education. For the next researcher it is suggested to use more indicators of academic information system variables, image and trust and enlarge the sample so that the result of research becomes more representative.

\section{References}

Ardianto. Elvinaro. Soemirat. (2007). Basic of Public Relations. Bandung. Simbiosa Rekatama.

Buttle, Francis. (2007). Customer Relationship Management: Concepts and Technology. Oxford: ButterworthHeinemann.

Fadeeva, Z., \& Mochizuki, Y. (2010). Higher Education for Today and Tomorrow: University Appraisal for Diversity, Innovation and Change Towards Sustainable Development. Integrated Research System for Sustainability Science, 249-256.

Ferdinand, Augusty. (2010). Management Research Methods. Semarang. BP Undip.

Ferdinand, Augusty. (2014). Structural Equation Modeling. Semarang. BP Undip.

Gorla, N. a, Somers, T. M. b, \& Wong, B. c. (2010). Organizational impact of system quality, information quality, and service quality. Journal of Strategic Information Systems, 19(3), 207-228.

Hasan.Y.. \& Shamsuddin.A. \& Aziati N. (2013). The Impact of Management Information Systems adoption in Managerial Decision Making: A Review. The International Scientific Journal of Management Information Systems. Vol.8(4). pp.010-017.

Helm, S. (2011). Employees' awareness of their impact on corporate reputation. Journal of Business Research, 64(7), 657-663.

Hotlan, S, Edwin C. (2014). Analisis Website Quality, Trust Dan Loyalty Pelanggan Online Shop. Jurnal Manajemen Pemasaran. Vol.8(2), Oktober 2014. 55-61

Kim, D. J., Ferrin, D. L., \& Rao, H. R. (2008). A trust-based consumer decision-making model in electronic commerce: The role of trust, perceived risk, and their antecedents. Decision Support Systems, 44(2), 544-564. 
Kountur, R. (2007). Research Methods For Writing the final project and Thesis. $2^{\text {nd }}$ Ed.Jakarta. PPM.

Lupiyoadi, Rambat, Hamdani, A. (2008). Marketing Management Services. Jakarta. SalembaEmpat

Nazir, M. (2012). Research methods. Ghalia Indonesia. Jakarta.

Raymond McLeod. Jr. George P. Schell. (2007). Management Information System. 10 ${ }^{\text {th }}$ edition. Jakarta.

SalembaEmpat

Raymond. L. \& Bergeron. F. (2008). Project management information systems: An empirical study of their impact on project managers and project success. International Journal of Project Management. 26 (2). 213- 220.

Rofiq, Ainur and Mula, Joseph M., The Effect of Customers' Trust on E-Commerce: A Survey of Indonesian Customer B to C Transactions (February 24, 2010). International Conference on Arts, Social Sciences \& Technology. Penang, Malaysia, 24 - 25 February 2010.

Sugiyono. (2012). Research Methods of Quantitative, Qualitative R\&D. Bandung. Alfabeta

Umar. H. (2011). Research Methods for Thesis and Business. $2^{\text {nd }}$ edition. Jakarta: Rajagrafindo Persada.

Venkatesh, V., Thong, J., \& Xu, X. (2012). Consumer acceptance and user of information technology: Extending the unified theory of acceptance and use of technology. MIS Quarterly, 36(1), 157-178.

Wahyudin, N. (2015). Analysis of Factors Affecting Competitive Excellence to Improve Private University Performance (PTS) At High School and Academy In Semarang. Holistic Journal of Management Research, 3(2), 7792. 